\title{
Mapping and Management of Stakeholder Relations in the Legislative Institutions of the Republic of Indonesia
}

\author{
Elly Yuliawati
}

Fakultas Ilmu Komunikasi Universitas, Mercu Buana, Jakarta 11650, Indonesia

Email: elly_yuliawati@mercubuana.ac.id

\begin{abstract}
The House of Representatives of the Republic of Indonesia (DPR RI) has made changes, adjustments to communication, governance and bureaucratic reform in an effort to become a Modern Parliament. Changes made need to be understood by all the stakeholders, so that problems do not arise in daily activities in carrying out their duties and functions. This study aims to map the stakeholders from the DPR RI and analyze the management of stakeholder relations conducted by the Indonesian Parliament in order to realize good government governance. The case study method is used to examine specific problems in stakeholder relations. The results of the stakeholder mapping of the Republic of Indonesia, there are three categories, namely, the internal public consisting of the Board and employees, the external public consists of the people such as press/media, and the Government/counterpart are the partners of the DPR. Stakeholder management carried out by the Indonesian Parliament through four stakeholder management processes, namely: Identification of Stakeholders, Stakeholder Management Planning, Management of Stakeholder Involvement, Stakeholder Engagement Control, through the educational activities and information about programs, activities, and performance achievements carried out by the board to a wide audience.
\end{abstract}

Keywords - Stakeholder Management,the House of Representatives, Modern Parliament, Good Government Governance.

\section{INTRODUCTION}

Good organization is an organization that continues to grow and evolve toward maturity in facing the challenges of the times that are likely to change even uncertain, as is always said to be the visionaries that the only certainty about the future is uncertain, the duty of the organization to build or establish uncertainty it becomes something that can be predicted direction of the change can be measured probability growth. Organizations must be able to map the changes in what is happening in their environment and how to anticipate or soluble precisely these changes that do not run over the times and keep their existence. Thus the organizational change is a must because in fact there is always a dynamic that continues to move within the organization and outside the organization.

The need for proper planning and management in order to achieve organizational goals as measured by effectiveness and efficiency. The effectiveness of the organization has a the effect of making contributions for themselves and the community, while efficiency is a measure of how management in the organization with minimal resources achieve the desired results.
The effectiveness and efficiency of the organization are always in demand internal and external environment, so the future also varies depending on claim or challenge. So that the change is a certainty, as well as the organization in the face of changes in the social environment which is preceded by changes in technology and efficiency, consciously or not have accepted the change even in the changes. In a situation of such rapid change driven by technological invention, change management provides guidance on how to deal with change, planning, adapting a change by the gradual or fast way just based on the ability of the organization's resources, so it is not hobbled in efficiency and no shock ineffectiveness.

House of Representatives of the Republic of Indonesia as a state institution has made changes as a way to respond to the challenges of the times. Departing from the findings of previous studies which realize good governance, the Parliament has a specific strategy that is becoming Modern Parliament, with three main indicators namely transparency, technology, and representation (Yuliawati, 2018). In an effort to become a Modern Parliament, has made changes and adjustments 
communication, governance, and bureaucratic reform. Through communication model successfully mapped four constitutive communicative genres that produce social structure through interaction, namely: self-structuring, negotiation membership, activity coordination, and institutional positioning. One of the adjustments made in the self-structuring expertise that is by establishing a Board of Representatives (BK DPR) whose position is equal to the Secretariat General of the Council of Representatives (DPR Secretary General) that already exist in the past. BK purpose of establishing the House of Representatives to support the work of the House of Representatives that are the substance, thus the work focus on supporting the Secretary General of the Parliament House of Representatives of an administrative nature (Yuliawati, Gusfa \& Prasetyo, 2018).

Any change will have implications, including in relations with stakeholders (stakeholder). The changes do need to be understood by all stakeholders, in order to avoid problems in everyday activities in carrying out its duties and functions. With the two bodies under the Secretary-General and the BK DPR, there must be a division of mutual support and may intersect, which can cause problems in the relationship of membership, authority, conflict of interest, and other friction.

a stakeholder is a popular term in management science in which the R. Edward Freeman (1984), which was first introduced. In the definition of a stakeholder is an individual or a group of people who can influence and be influenced by the organization (Freeman, 1984) In Advanced stakeholders is divided into two major groups namely internal stakeholders and external stakeholders. Refers to the external stakeholders and external to the organization or community whose presence could affect or be affected indirectly running of the organization. Average internal stakeholders are individuals or groups of people who could influence the course of the organization directly among employees and directors.

Internal communication process organization at the Secretariat General of the Parliament be it communication downward (downward communication), communication upwards (upward communication), horizontal communication, as well as interline communication is made orally, the disposition assignment, and / or through a letter of assignment and utilize internal communication media in the form of bulletin "parliamentarian" Lawmakers and Internal Employee Portal (Yuliawati \& Prasetyo: 2016). It shows that there is an internal communication channel at the Parliament that needs to be managed to see how the Parliament can manage both internal and external communication to realize the goal of becoming a modern parliament.

Identification of the problems that may affect stakeholder relationships must be managed in a slick and constructive, to maintain the relationship in good condition and positive for the organization. For the study of managing stakeholder relations into urgency in this study. Use of the case study method to parse the specific problems in relation to stakeholder relations, gather information through interviews and documents, as well as referring to the theory of stakeholder relations management. Mapping, management and communication strategy in stakeholder relations generated in this study, a solution and a recommendation for the development of good governance in the House of Representatives of the Republic of Indonesia.

\section{METHODOLOGY}

The nature of this research is descriptive case study method. The descriptive study not only lays out (analytical) but also blends (synthesis). In a descriptive study of data obtained is not in numbers but in the form of word sentences, statements, and concepts. The descriptive study only describes the situation, do not look for or explain the relationship, do not test hypotheses or make predictions (Rachmat, 2002). Data were collected through in-depth interviews with sources who have the competence and knowledge related to the management of stakeholder relations in the House of Representatives in an effort to become a modern parliamenttoestablishgoodgovernance.

In the principle, the qualitative data analysis was carried out together with the data collection process. The techniques of data analysis according to Miles and Huberman include three concurrent activities: 1) Data reduction. The field data obtained through observation and interview in the form of field notes and recordings are quite a lot and difficult for the researcher to understand, then the data reduction is carried out, 2) Data Display. To facilitate reading the data obtained, the data that has been reduced is then presented (displayed) in the form of a thorough description of every aspect studied by being equipped with tables / charts, the relationships between categories and its kind, 3) Verification is interpreting the data that has been compiled. Based on these interpretations, the researcher can arrange into a conclusion, where this conclusion is the result of research that can answer the research questions that have been formulated previously (Irawan, 2018: 118).

To ensure that the research data is valid, the process of checking the validity of the data is carried out. 
For this reason, Miles and Huberman explains that the technique of checking data validity includes three concurrent activities: data reduction, data display, and conclusion (verification). Then to determine the data validty, the researcher conducted a triangulation technique. According to Moleongthe researcher compares and checks the degree of trust of information obtained by: (1) comparing the observational data with interview data (2) comparing the consistency of the answers of the interviewees, namely by comparing what the speakers said in front general for example, with what is said personally (3) comparing a person's perspective, with other people in his work team (Kurniastuti, 2018: 53).

\section{DISCUSSION}

\section{Stakeholder Mapping of Parliament}

House of Representatives as the Institute for representatives of the people who have different characteristics from the Institute of other State, has the vision to bring the Parliament into representative institutions of modern, credible and authoritative, these efforts continue to be made to achieve the goals and ideals of expected that to achieve governance good (good governance). By carrying out the strategy as a modern Parliament in strengthening its institutional commitment.

The three main requirements that must be met by the Parliament in realizing Modern Parliament: first, related to the accessibility of transparency or disclosure of information to the public. The second, related to the representation of the role of front members in representing the interests of their constituents. Third, information technology supports the performance of the House of Representatives to take advantage of the technology. The third element is an indicator designed to achieve the expected goals.

In the era of globalization and rapid technological developments access to all the information is very open. All parties that have an interest can access the information it needs from each agency. Indonesia is a democratic legal state that is implementing a state system based on the mandate from the people, the people have a right to information about the activities or the achievement of the people representatives in this Parliament.

Stakeholders are individuals, groups, or organizations that consider themselves affect or be affected by the decisions, activities, or the result of a policy or a program organized by institutions/ organizations (Bourne, 2015). The role of stakeholders for the development of the organization/ institution seen growing in an environment that can not be predicted at this time, so that the organization/institution will seek the support of stakeholders to prepare themselves to face the challenges ahead (McDonald \& Cokley, 2013)

In reaching out and embracing each stakeholder owned by the House of Representatives would require the role of Public Relations (PR) in implementing an effective communication strategy to maintain and to establish the existence and continuity of an institution/organization. Although it is imperative to achieve good governance is not only done by the PR House of Representatives but with the support of all the units in the Secretariat General of the Parliament to work together to realize the harmonious management function in its commitment into a modern Parliament.

Stakeholders have the right to get the information they need and agencies / organizations that implement good governance also required to provide disclosure of information about any achievements, activity, or policies that made (Logsdon and Lewellyn, 2000) stakeholder environment of the House of Representatives has a very important role this because the role of the Parliament which is getting stronger and strategically in the organization of the state so that the Parliament is not only complementary but can be a determinant representing the people of Indonesia.

Stakeholders can be classified into two categories: primary and secondary stakeholders. The primary stakeholders are individuals or groups who have a formal relationship with the organization directly, while the secondary stakeholders are agents that are not directly related to the organization but can influence and be influenced by policies, programs and activities (Gomes, 2006). three main groups of stakeholders, namely: internal stakeholders, external stakeholders, and media stakeholders (Koehler \& Raithel, 2018). In this case, the House of Representatives serving the public categorized into three sections: the internal public is composed of the Board and employees, external public consists of a society in which there is a press/media, and government/counterpart implementing partners of the House. An organization/institution tends to focus on because of the wide range of external stakeholders that must be maintained and therefore considers that the internal stakeholders are relatively easy to set up and nurtured. But it is an error that occurs in an institution / organization for internal stakeholders like employees like main engines that determine the sustainability of the organization to achieve the expected goals (Yuliawati \& Prasetyo, 2016) in identifying Stakeholder House of Representatives this study refers to the division of the stakeholder group based Linkage Model as shownbelow: 


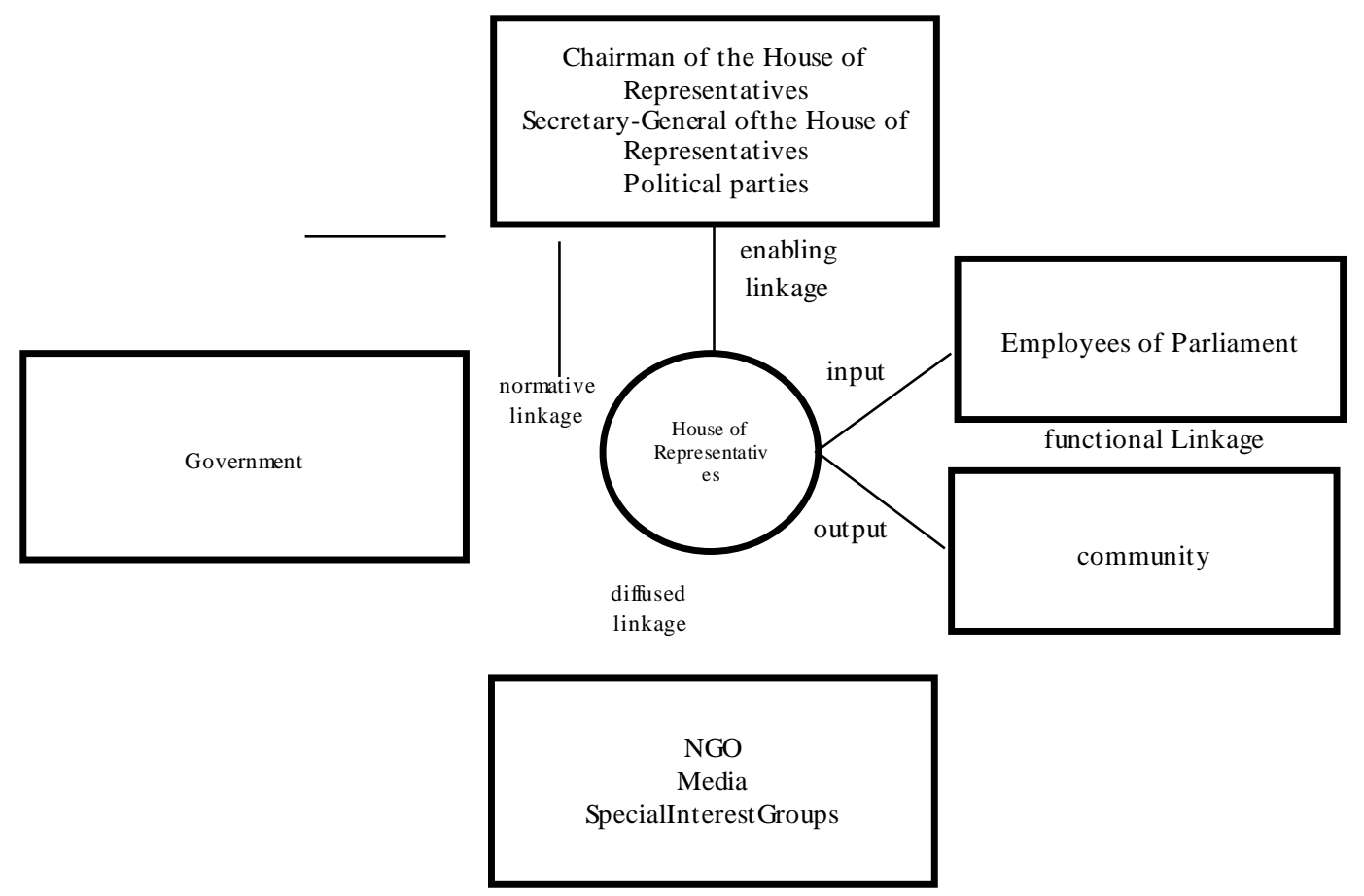

Fig.1: Mapping Stakeholder House ofRepresentatives

(Source: Data processing by the Research, 2019)

Enabling Linkages: Identifythe stakeholders who have control and authority over resources for the organization so that they can survive its existence, in this case, the Chairman of the House of Representatives is the highest leadership in the administration of the organization, then Secretary General of the House of Representatives which has the power associated with the administration all the needs of the board with all the instruments and the role and function makes the Secretary-General of the House of Representatives also have control over the 1300 military/subordinate employee. And political parties that are also included in the enabling linkage because the party is the one who has the authority to choose its candidate to parliament and also recall its members.

functional Linkages: Stakeholders are important for the functioning of the organization, and is divided between the input function that provides manpower and resources such as employees of the General Secretariat of Parliament who perform functions in each unit to support the purposes of the council in accommodating the aspirations of the community, helping people to each area for recess and others. as well as the output function that is consuming the results of an organization, in this case the public as the party to receive and feel the service or the requirements given by the House of Representatives.

normative Linkages: Identifying stakeholders with notice by any common problems, interests relationship with groups, associations or institutions that have similar goals. In this case, the incoming government is a stakeholder in the normative linkage for the government as a partner of the House of Representatives who has the same goals and interests are for the welfare of Indonesian society.

diffused Linkages: This relationship is the most difficult to identify because they include stakeholders who do not have any interaction with the organization, but engaged based on the actions of the organization. A public that often arises in times of crisis. Included in the category of linkage is diffused media, NGOs or other special interest groups. The emergence of linkages diffused out of the role of mass media. The mass media have a role in conveying all relevant information Parliament to other audiences. Sufficient public interest group influence as an example of the media. Social media also included a great influence institutionally as it sounds netizen affect the performance of the Parliament itself. In addition a kind of institutional association in the community, in accordance with the interests of its is sue as Laboror PGRI.

\section{Manage Stakeholder Relations House of Representatives}

Establish and maintain relationships with stakeholders is not a simple task in an environment that is rich in information, this time a lot of information or messages organization provided but can be thrown at 
random and unstructured environments, especially the spread of information in online media (Luoma-aho, 2015). According to Torfaen County Borough Council (TCBC) in Revit Project (2006), the expected goal of build relationship with stakeholders is to improve personal relations/labor; changes in perception in the community or other audiences and strategic communication quality is getting better with stakeholders. public Relations of an organization must be able to run the management of strategic communications with stakeholders to be able to manage the interests related to issues that must be faced and help strategic decision makers in determining where the most important stakeholder to make a decision (Grunig, 2002). There are four processes in stakeholder management, namely:

\section{Stakeholder Identification (Initiating)}

In the first phase of stakeholder management is to identify the stakeholders with two strategic steps that need to be done, 1) to understand the is sues related to the organization/institution, 2) understand the characteristics and types of stakeholders.

The first step, in this case, the House of Representatives need to understand the issues related to the growing community of Parliament. Social is sues can be the issue on the political situation, the quality of education, skills development, technology development or the welfare of the Indonesian people.

In this first step publicist House of Representatives has a specific strategy, in addition to identifying the issues raised in the House PR people make such a strategy the Create Issue or create a separate issue to minimize the bad news to the House of Representatives. PR House of Representatives will be more focused to make issues related to the performance of the board, achievement and ongoing activity to be made public.

Step Two, understand the characteristics and types of stakeholders of the House of Representatives. After mapping the stakeholders of From the type, stakeholders can be divided into the key stakeholders, major stakeholders, stakeholder support, stakeholder complementary. From its characteristics, can be divided into stakeholder disorganized, half-organized stakeholders and stakeholders are organized. By knowing the characteristics and types of stakeholders Public Relations of the House of Representatives will be easier to create a plan for managing relationships with all stakeholders to achieve the desired objectives.

\section{Stakeholder Management Planning (Planning)}

An organization/institution countries are expected to take steps with good stakeholder management planning in accordance with the expected values and goals together. Stakeholders should be planned management to produce the output of the process of stakeholder management in the form of an official document. In a stakeholder management thing to note is planning to set up a strategic communication that can be used to convey an internal message effectively so as to be understood by internal stakeholders in an effort to the development and progress of the institution / organization in this case the House of Representatives (Yuliawati \& Prasad, 2016). There are two stages of the planning done by the House of Representatives as a business stakeholder management is a socialization and externalization.

Socialization activities in this regard such as sharing, meeting face to face for meetings, discussions and monthly meetings. The activity is delivered with presentation techniques in oral and written and video lessons, followed by discussion, questions, and answers, as well as providing advice and input, in this meeting discussion on planning in stakeholder management would be discussed related to information should be presented to the public and through any media, This stage becomes a process of coordinating and setting up communication strategies.

Activity externalization is the process of recording the contents of each meeting to be a repository of materials that will be archived in each unit so that when there is a request data through the PPID, Public Relations of the House of Representatives will coordinate with each unit in order to distribute the information needed by the public.

\section{Stakeholder Engagement Management (Executing)}

In its management expertise required communication, and management in implementing all plans and preparation of stakeholder management. Stakeholder management can be achieved through a variety of forms and strategies undertaken by the House of Representatives focused on educational activities by providing information about the activities, achievements, and programs carried out by the board to a broad audience.

One of the activities are always carried out in order to provide knowledge on the Parliament to the public is an usher educational activities. Guest education is a program to receive guests from various backgrounds ranging from early childhood education institutions to universities, communities, government agencies, and the general public.

In order to realize good governance, through the 
commitment of modern parliamentary House of Representatives is ready to serve every community who require information related to the House of Representatives. Public Relations of the House of Representatives through its activities trying to make Parliament an institution that is transparent, effective and informative. public disclosure made by the House of Representatives is one of them PPID (Acting Manager of Information and Documentation), PPID is managed by the PR DPRI RI have a duty to plan, organize, implement, and evaluate the implementation of management activities and public information services within the Secretariat General and Skills Agency DPR (website ppid.dpr.go.id).

Public Relations of the Parliament contribute to coordination with internal units related public information services, documentation and records required by the public so that all forms of the purposes of data information required from the door of the PPID, this is an attempt to achieve good governance through the ministry of the disclosure of information with external stakeholders, Flow internal data management is managed by the Public Relations of the House of Representatives, PPID will process all incoming data and the request will be forwarded to each unit.

\section{Stakeholder Engagement Control (Monitoring-Controlling)}

Organization/institution is expected to be monitoring and evaluation of the program or activity that has been done in the management of stakeholder relations, including an assessment of the quality of relationships with every stakeholder institutions. Monitoring and Controlling are done to see the organization commitments with both internal and external stakeholders, the participation of stakeholders in every process of managing stakeholder relations, outcomes or benefits are obtained and related reporting aspects that must be improved to achieve institutional objectives. The results of this phase are aimed to produce an evaluation report related to communication or repair things that it is still not as well as related reporting of the results of the stakeholder management process.

Control of stakeholder involvement in evaluation activities are also carried out by the Parliament on changes to existing, Parliament evaluates internally as a form of coordination and precaution against risks that must be faced. Internal evaluation conducted of Parliament as government efforts in achieving good governance routinely done through teamwork. The team had full responsibility in ensuring that programs/activities which they are responsible can be accomplished in accordance with the planned target and within the time period specified.

In addition, also held internal meetings related monitoring activities or policies that need to be discussed with the relevant units commonly referred Rabuan attended by leaders who can provide motivation, punishment, for example, in the context of actuating and controlling up to the evaluation of any program or activity,

PR House of Representatives as a unit which has an important role in stakeholder management and main implementer PPID also helped to educate every internal unit of Parliament to monitor any data and information on each unit, so that when a request for information from the public PPID can be makes it easy to serve and meet the needs of the information requested, so that the performance of the House of Representatives may be more informative and creates the smooth running of the process of information disclosure.

Collaborative relationships with internal and external stakeholders are key in creating an organization/institution more competitive in the era of the global economy that requires every organization must be able to adapt and integrate every line in stakeholder management in order to achieve the expected results (Andrilla. 2014).

Through public disclosure is a form of the commitment of the agencies in realizing the implementation of good governance (good governance). Systems were well arranged and accompanied by the implementation and enforcement of discipline will create governance in good order. Implementation and enforcement are judged on nine characteristics defined by UNDP: Participation, Rule of Law, Transparency, Responsiveness, Consensus Orientation, equity, effectiveness and efficiency, accountability, and strategic vision. (UNDP, 1997), With the existence of public information disclosure through PPID which is managed by the Public Relations DPR RI, it is a form of implementation of good governance.

\section{CONCLUSION}

The conclusions of this study are House of Representatives serving the public categorized into three parts, namely the internal public consisting of the Board and employees, external public consists of a society in which there is a press/media, and government/counterpart implementing partners of the House of Representatives, and stakeholder management is done by the various forms of activity in accordance with the stakeholders to reach, but the strategy undertaken by the House of Representatives focused on educational activities through 
the information activities, achievements, and programs carried out by the board to a broad audience. House of Representatives run into four processes in stakeholder management, namely: Stakeholder Identification (Initiating), Stakeholder Management Planning (Planning), Stakeholder Engagement Management (Executing), Stakeholder Engagement Control (Monitoring - Controlling)

\section{REFERENCES}

[1] Andrilla, Riska. (2014). Implementation stakeholder Plus Relationship Management (SRM +) in the Management of Operational Area Community Development at Total E \& P Indonesia. Journal of Communication, 2 (3) 333-346. ISSN 0000-0000, journal.ilkom.fisip-unmul.ac.id

[2] Bourne, Lynda. (2015). Targeted communication: the key to effective stakeholder, 29th World Congress International Project Management Association (IPMA) in 2015, IPMA WC 2015, The Westin Playa Bonita, Panama

[3] Freeman, R. Edward. (1984). Strategic Management: A Stakeholder Approach, Pitman Publishing, Boston.

[4] Gomes, Ricardo Corrêa. (2006). Stakeholder Management in the Local Government Decision-Making Area: Evidence from a Triangulation Study with the English Local Government, BAR, v. 3, n. 1, art. 4, p. 46-63, Jan./June

[5] Grunig, James E. Grunig, Larissa A., Dozier, David M. (2002). Excellent Public Relations and Effective Organizations. London: Routledge.

[6] Irawan, Enjang Pera. The Analy sis of Triple Bottom Line Concept Implementation in CSR Program through Local Food Processing Industry. International Journal of Management Sciences and Business Research, April-2018 ISSN (2226-8235) Vol-7, Issue 4

[7] Kurniastuti, Kusuma. Activities of the Cyber Public Relations of O Chanel TV in Promoting their Company on the Instagram Social Media. American Journal of Humanities and Social Sciences Research (AJHSSR) eISSN: 2378-703X Volume-02, Issue- 09, pp-50-56.

[8] Luoma-aho, Vilma. (2015). Understanding Stakeholder Engagement: Faith-holders, Hateholders \& Fakeholders. Research Journal of the Institute for Public Relations Vol. 2, No. 1

[9] Logsdon, JM and Lewellyn, PG (2000). Expanding accountability to stakeholders: Trends and predictions. Business and Society Review 105 (4), 419-35.

[10] McDonald, LM \& Cokley, J. (2013). Prepare for anger, look for love: A ready reckoner for crisis scenario planners. Prism 10

[11] Muhshi, Adam. (2018). Fulfillment of the Right to Public Information as State Responsibility in Creating Good Governance, Lantern's Law, Volume 5 Issue 1 pp. 59-70 doi: 10.19184 / ejlh.v5i1.7284

[12] Prasetyo, Kurniawan. (2016). Coalition Dominant Dpr PR-Ri For Boundary Spanner In Achieve Good
Governance Through Public Information Media Kom Journal, Vol. VI, 2 December

[13] Torfaen County Borough Council. (2006). Stakeholder engagement -A Toolkit. REVIT Project.

[14] Yuliawati, Elly \& Prasetyo, Kurniawan. (2018). Legislative Reform bureaucracy implementation of the Faculty of Psychology and Communication, University of Mercu Buana, Jakarta

[15] Yuliawati, Gusfa, Henni \& Prasetyo, Kurniawan. (2018). Mapping Changes in the Development of Communication and Government Good Governance in the House of Representatives, Mercu Buana University Research Center, Jakarta. 